\title{
Effects of Brand Heritage on Intentions to Buy of Airline Services: The Mediating Roles of Brand Trust and Brand Loyalty
}

\author{
Deniz Zeren ${ }^{1, *(1)}$ and Ali Kara ${ }^{2}$ (1) \\ 1 Department of Business Administration, Cukurova University, Adana 01250, Turkey \\ 2 Department of Business Administration, Penn State University York, York, PA 17403, USA; axk19@psu.edu \\ * Correspondence: dzeren@cu.edu.tr
}

Citation: Zeren, D.; Kara, A. Effects of Brand Heritage on Intentions to Buy of Airline Services: The Mediating Roles of Brand Trust and Brand Loyalty. Sustainability 2021, 13, 303. https://doi.org/10.3390/su13010303

Received: 8 December 2020 Accepted: 27 December 2020 Published: 31 December 2020

Publisher's Note: MDPI stays neutral with regard to jurisdictional clai$\mathrm{ms}$ in published maps and institutional affiliations.

Copyright: (C) 2020 by the authors. Licensee MDPI, Basel, Switzerland. This article is an open access article distributed under the terms and conditions of the Creative Commons Attribution (CC BY) license (https:// creativecommons.org/licenses/by/ $4.0 /)$.

\begin{abstract}
Brands are facing significant pressures in globalized markets so as to communicate a consistent corporate identity to their customers. Accordingly, the established past of a brand should be considered a key resource by giving the organization a competitive advantage in the marketplace. This paper examines the relationship between brand heritage and consumers' purchase intentions of airline services and investigates the mediating roles of trust and loyalty. We conceptualize that brand heritage will have a positive effect on consumers' purchase intentions of airline services. Moreover, using the Commitment-Trust Theory (Morgan and Hunt, 1994), we hypothesize that brand trust and brand loyalty will mediate the relationship between brand heritage and purchase intentions. Data for the study $(n=567)$ is collected through personal interviews of airline passengers traveling from 10 different major airports in Turkey. Results reveal that brand heritage has a significant positive direct effect on purchase intensions; however, when the brand trust and brand loyalty constructs are introduced into the model, the direct effect becomes statistically insignificant, demonstrating full mediation roles of brand trust and brand loyalty on purchase intentions. Research and practical implications are discussed.
\end{abstract}

Keywords: brand heritage; brand trust; brand loyalty; mediation; airline services; purchase intentions

\section{Introduction}

It is known that branding is a critical part of marketing strategy and when implemented effectively, it can lead to customer loyalty, higher levels of intentions to purchase, and improved company success. Brands are known to send various signals to customers that help them in their product evaluations and ease the discomfort felt in their purchase decisions. However, creating, maintaining, and adapting successful brands is challenging, takes a long time, and requires significant financial commitment [1]. Previous research on branding has emphasized that successful brands are the ones that communicate a clear and consistent message, differentiate company offerings, and deliver the promises made [2].

Over the last three decades, marketing literature has provided a plethora of studies that have focused on conceptualizing, measuring, and testing the role of brand equity on various intermediate factors such as loyalty, trust, and company performance. Later, the focus of brand research has evolved into a brand-identity based framework. A well-defined corporate brand identity is considered crucial in brand strategy. More recently, the research focus has shifted to examining the role of brand heritage (e.g., brand's track record and past) as a factor in differentiating and positioning a company's brand [3-7]. Brand heritage is argued to have become more important and its placing emphasis on its history/longevity is expressed to amplify a brand's communication power.

Accordingly, Urde et al. described brand heritage as " ... longevity, core values, use of symbols, and the organizational belief that its history is important" ([7] p. 4). They argued that brand heritage enables a brand to protect its future by harnessing the value from its 
past and present. Parallels between the monarchies and brand heritage are made where a symbolic communication is used to emphasize their history as part of their identity. Hence, brand heritage is assumed to reinforce the stability in an image needed to create consumer trust in a brand by connecting it to the past without creating a perception of an outdated company [8]. Wiedmann et al. [5] and later Merchant and Rose [9] offered scales for measuring brand heritage. Wiedmann et al. [5] conducted their quantitative investigation on the automotive industry in Germany and tested various antecedents and consequences of brand heritage. On the other hand, Merchant and Rose [9] study investigated brand heritage in the advertising context without a focus on how brand heritage influenced relationships among critical success factors in a broader marketing context. More recently, Rose et al. [3] tested the outcomes of brand heritage on consumers' purchase intentions and reported that brand heritage has affective and cognitive consequences (e.g., positive emotions and commitment). Applications and testing of brand heritage in the tourism industry can also be found [10].

Travel restrictions, suspension of flights, and experts' advice for avoiding air travel as much as possible due to the pandemic have created very challenging times for airlines industry. Hakala et al. [8] argued that a brand's ability to portray stability and trust based on its established past or longevity might be an effective way of enduring such environmental turbulence. Thus, it is understandable why consumers would seek comfort and security when their routine lives have been interrupted. Moreover, consumers' trust, connection, or emotional attachment with brands that have brand heritage can play an important role in their purchase decision [11-13].

In this study, we focus on investigating the relationship between brand heritage and consumers' purchase intentions of airline services in a culturally different emerging market. More specifically, we focus on examining the mediating effects of brand trust and brand loyalty in facilitating the relationship between brand heritage and purchase intentions. We aim to fill the gap in the literature by empirically investigating the consequences of brand heritage. Although Wiedmann et al. [5], included both brand trust and brand loyalty as variables in their model, they tested a more complex model where some of the effects might have been distorted by the existence of the other variables in the model. Hence, using the Commitment-Trust Theory by Morgan and Hunt [14], we simplify the relationships in the model and deduce the relationships among constructs in a culturally different market and competitive service industry-airline services, which has been going through turbulent and uncertain times due to COVID-19 pandemic.

\section{Literature Review}

\subsection{Brand Heritage}

Brand heritage is defined as " ... a dimension of a brand's identity found in its track record, longevity, core values, use of symbols and particularly the organizational belief that its history is important" ([5] p. 4). Track record refers to the evidence of the brand's existence for a long time and its successful delivery for promising to satisfy their customers. Identity of a brand is closely linked to its past, present, and future successes and accomplishments. Brand history is a valuable signal for consumers, and it enhances their perceptions of authenticity [15]. Information about the roots of brand heritage and symbolism of the brand contribute to brand differentiation and enhance brand personality through consumers' previous experiences of the brand and interpretations of those experiences in contemporary times [1].

Although the brand heritage concept has been around in the literature for a long time, scholarly interest in this topic has been brought up during the last decade and a half. Several studies have examined brand heritage in the context of automobiles [5,7,16], furniture [7], banking [7], tourism [17], and food industries [8]. Building successful brands requires the development of a brand identity that consists of a unique set of brand associations and communicates a promise to its customers [18]. As a dimension of the brand's identity, brand heritage is an extrinsic cue developed by the marketing strategy that communicates 
valuable information to its users [7]. Literature suggests that brand heritage perceptions have found to be associated with expertise, legitimacy, authenticity, brand value, and responsibility [5-7,19-21]. Having an established past is not enough for building brand heritage but rather it needs to be enhanced or created by marketing mix strategies [9] through interpretations [1] and the use of symbols to communicate corporate values and beliefs $[5,8]$. Additionally, most consumers do not have much information about corporate heritage, and they form their brand heritage perceptions based on what is communicated to them via the company. Literature accentuates that marketers use distinct strategies such as narrating, visualizing, performing, and embodying to develop brand heritage [22].

\subsection{Brand Trust}

Moorman, Deshpande, and Zaltman [23] define trust as "a willingness to rely on an exchange partner in whom one has confidence" (p. 315). Sherman [24] argued that trust is a crucial factor for the success in any strategic alliances and Spekman [25] described trust as the "... cornerstone of strategic partnerships." Trust, therefore, is a critical factor between the two parties in a successful relationship. Trust includes feelings that consumers can rely upon the company and with the lack of such feelings lead to, hesitations in getting into exchanges with companies [26]. With respect to implications of trust (or the lack of) on business exchanges, Moorman, Deshpande, and Zaltman [23] and Morgan and Hunt [14] used the trust construct as an important factor to predict consumers' future intentions.

Chaudhuri and Holbrook [27] define brand trust as consumers' willingness to rely on the brand to realize its stated promise. Morgan and Hunt underline that trust exists "... when one party has confidence in an exchange partner's reliability and integrity" [14] (p. 23). Customers who have higher levels of brand trust, therefore, expect that there will be a satisfactory resolution to their problems with the service provider in the case of service failures [28]. Hence, the existence of trust eases discomfort felt and facilitates customers' purchase decisions. Schurr and Ozanne [29] report that trust is central to achieving cooperation and find that trust leads to higher levels of loyalty. Similarly, Aydin and Ozer [30] and Dehdashti, Kenari, and Bakhshizadeh [31] reported that trust is the most important antecedent of brand loyalty because it creates an ongoing process for continuation and maintenance of the relationship. Hence, literature provides support for the role of trust in moderating loyalty and strengthening customer commitment [32]. A consistent brand identity (e.g., brand heritage) can have a positive impact on trust, loyalty, and commitment.

\subsection{Brand Loyalty}

The central tenet of marketing philosophy is to create customer loyalty by satisfying their needs to achieve lifetime customer value. Lifetime customer value is realized when customers prefer and repurchase a firm's offerings again and again. As aforementioned, trust is considered an antecedent for building and maintaining relationships with customers [14]. Literature provides information that brand trust leads to brand loyalty where trust creates an ongoing process to continue and maintain relationships $[14,33]$. When consumers develop trust in a brand, they perceive less risk in the future purchases of this brand [27], hence, leading to their loyalty. Accordingly, loyalty is defined as " . . a deeply held commitment to rebuy or re-patronize a preferred product or service consistently in the future, despite situational influences and marketing efforts having the potential to cause switching behavior" ([34] p. 34). From a different point of view, Hirschman ([35] p. 78) describes loyalty in terms of expectations that he/she will act in the future. Jacoby and Kyner explain brand loyalty as " . . a a biased (i.e., nonrandom) behavioral response (i.e., purchase) expressed over time by some decision-making unit with respect to one or more alternative brands out of a set of such brands and as a function of psychological (decision making, evaluative) processes" ([36] p. 2).

According to Oliver [34], loyalty influences customers' cognition, affect, conation, and behavior. In other words, loyalty may be (1) the perception of brand attributes of a 
brand being preferable (cognitive) to other alternatives, (2) developing a liking or positive attitude toward a brand (affective), (3) a strong desire or commitment to buy the brand again (conative), and (4) actually rebuying the brand (behavioral). In this study, similar to Uncles et al. [37], we mainly use loyalty from a conative and attitudinal (loyalty is viewed as an intention to act) perspective and consider it as a consequence of trust. We consider brand loyalty a strategic competitive advantage because recruiting new customers costs more than keeping the existing ones and reduces competitive pressures for customer attrition.

This study uses the Commitment-Trust Theory [14] to conceptualize the relationships among study constructs, brand heritage, brand trust, brand loyalty, and purchase intentions of airline services. The theory by Morgan and Hunt [14] conceptualizes trust as the key mediating variable for relationship commitment. Using the research evidence established in the organizational behavior literature, they conceptualize that trust influences the relationship commitment for several reasons. They also posit that relationship commitment and trust lead to desirable qualitative outcomes such as not leaving the relationship, reduced uncertainty for decision-making, and encouraged cooperation. Since the perceived trust reduces decision-making uncertainty, one could argue about the positive relationship between trust and loyalty [5]. Furthermore, various empirical research has shown that loyalty positively influences customers' intentions to buy the brand in the future [38]. Figure 1 illustrates the conceptual model tested in this study.

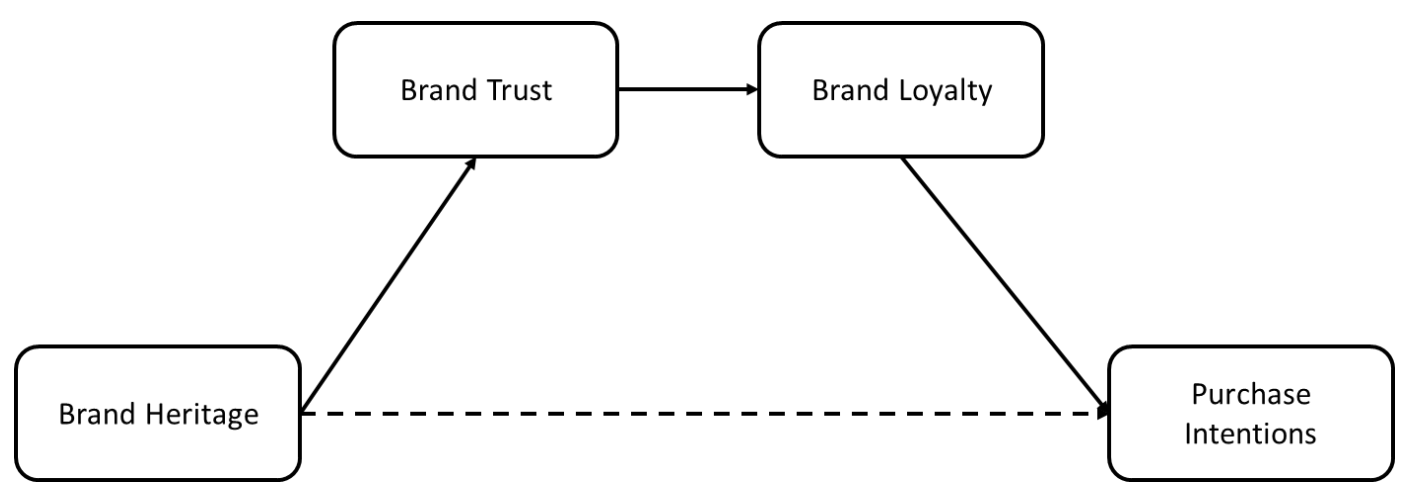

Figure 1. Research model.

Wuestefeld et al. [21], tested a conceptual model where brand heritage is hypothesized to influence customers' perceived value. As part of the corporate brand identity, brand heritage is assumed to make a brand more authentic, credible, and therefore provide an advantage for the brand in confirming customer expectations that the brand will deliver its promise. They reported that brand heritage positively influenced the perceived economic, functional, affective, and social value of a brand, and concluded that brand heritage affects the overall perceived value. Similarly, other previous research emphasized the importance of brand heritage on creating perceived authenticity [39], communicating a sense of stability [5,6,8], and originality [39]. Hence, in their study, Rose et al. [3] hypothesized that brand heritage positively influences customer purchase intentions. Their findings revealed that the relationship was significant and positive, especially, when the brand heritage inspired positive emotions and trust. The hypothesis is given as follows:

Hypothesis 1 (H1). Brand heritage will have a positive impact on consumer purchase intentions.

\subsection{Mediating Role of Trust and Loyalty}

Previous research has emphasized that brand heritage influenced customers both cognitively and emotionally. Using the signaling theory [40], researchers state that the cognitive outcomes of brand heritage usually show up in the form of customers trusting the service provider [41,42]. More specifically, consistency in brand performance over 
time should have a positive effect on consumer trust because of the expectancy and performance match. Brand trust and loyalty are considered social emotions or feelings that are closely associated with improved cooperation [26]. Hence, it is argued that trust precedes cooperation [43]. Previous scholars emphasized the important role brand trust plays in brand loyalty $[27,44]$. Although the relationship between trust and loyalty is not simple, trust has been considered as an antecedent for building and maintaining loyal relationships with customers [14]. Whenever customers perceive if/incase a company cares for the needs and benefits of its customers, the trust in the relationship will get strengthened [45] because of the positive emotions. As the trust levels get higher, the commitment of customers to the exchange relationship increases. Oliver [34] defined loyalty as " ... a deeply held commitment to rebuy or re-patronize a preferred product or service consistently." Hanzaee and Andervazh [46] and Chen [47] used trust as a mediator of brand loyalty.

As a part of the corporate identity, brand heritage is assumed to send signals about the firm's offerings and contribute to improved trust, loyalty, and commitment [32]. In other words, we conceptualize trust, loyalty, and commitment as consequences of brand heritage. Loyal customers will be less likely to pay attention to competitors' offerings and will not consider switching because they perceive a differentiated value in the brand [48]. In the same vein, Jacoby and Kyner [36] deduced that repeat purchasing behavior and brand loyalty are not the same because they are mediated by different underlying dynamics. Partially replicating the previous research [32], we hypothesize that brand heritage influences consumers' emotions, trust, and brand commitment as underlined within the hypotheses given below:

Hypothesis 2 (H2). Brand heritage will positively influence perceived trust.

Hypothesis 3 (H3). Higher levels of perceived trust will lead to higher levels of customer loyalty.

Hypothesis 4 (H4). Higher levels of customer loyalty will positively influence purchase intentions.

Hypothesis $\mathbf{5}$ (H5). The positive effect of brand heritage on purchase intentions is mediated by (a) brand trust and (b) brand loyalty.

\subsection{Turkish Airlines and Brand Heritage}

Turkish Airlines was established in 1933 by the founder of the Turkish Republic and started its first international flights in 1967. In 2006, Turkish Airlines has become a member of the world's biggest airline association, Star Alliance and in 2012, it was selected as the best airline company in Europe [49]. Turkish Airlines implements a carefully designed brand heritage program internally through various strategies such as narrating, performing, and articulating it externally at a brand level. Turkish Airlines emphasizes its brand heritage through symbols such as a founding date, a character, a mention, or references to the company's history. Using a qualitative study, Maden [49] reported that Turkish Airlines was considered, as a brand, the embodiment of traditional Turkish culture's hospitality and warmth. Customers associated the Turkish Airlines brand with being rich in cultural heritage and distinct from its existing competitors. They indicated that Turkish Airlines has a legendary image, and they are proud of having such a successful global company in their country.

However, being the first airline in Turkey is not simply sufficient to have such strong heritage associations with its brand. Using very successful international public relations and advertising agencies [50], Turkish Airlines' marketing communications strategy consistently emphasizes a corporate image by focusing on its roots, cultural values, heritage, service quality, tradition and modernity, being a strong global player, and Turkish identity. For instance, a specific city or local Turkish town name is printed on each aircraft and clearly visible to customers when boarding the aircraft. Erdem and Swait indicate 
that through marketing mix strategies, a firm's brand becomes " . . a signal because it symbolizes its past" ([50] p. 135). Consumers use this signal to reduce decision-making uncertainty in the product evaluation process. Hence, we believe that the profile of Turkish Airlines exemplifies a brand heritage in practice framework as suggested by Urde et al. [7]. Hence, we have selected Turkish Airlines to investigate our study hypotheses regarding the outcomes of brand heritage.

\section{Materials and Methods}

\subsection{Data Collection and Sampling}

Data for the study was collected using personal interviews in several Turkish airports using the intercept method between 15 June and 1 August 2019. The 10 most popular airports were targeted for data collection (Istanbul, Ankara, Izmir, Adana, Trabzon, Samsun, Gaziantep, Erzurum, Van, and Amasya). Passengers in the airports were approached by the interviewers randomly and they were invited to participate in the study by stating that their identity will be confidential. Although the participation in the study was completely voluntary, the interviewers used their judgment in selecting/approaching the subjects. However, the interviewers were advised to approach a diverse group of passengers based on age, gender, and other visible characteristics (e.g., business attire, etc.). Such sampling methods have also been utilized in the literature ([51] p. 394) ([52] p.428).

Since we did not have a known sampling frame, we used the sample size determination formula in deciding the sample size needed for our study. Previous studies have indicated that approximately $90 \%$ of the working population could be used as a basis for such studies when using the sample size determination formula to estimate the sample size [53]. With a 95\% confidence interval and a 5\% of acceptable error level, the sample size determination formula yielded a sample size of $n=384$ observations. Based on the resource availabilities in the data collection process, we determined that we could reach out and interview a significantly larger number of participants. As a result, a total of 568 travelers over 18 years old were approached and invited to participate in the study in the 10 selected airports in Turkey. The final usable dataset consisted of a sample size of $n=567$.

\subsection{Questionnaire and Constructs}

Study questionnaire comprised three parts. The first part of the questionnaire included questions about participants' familiarity with various airline brands including Turkish Airlines. In addition, travel frequency, reasons for travel, and factors influencing airline selection decisions were also included in this section. The second part of the questionnaire included scale items to measure constructs used in the conceptual model. A five-point Likert-type rating scale ranging from 1 being "Strongly Disagree" and 5 being "Strongly Agree" was used for all scale items.

Scale items for brand heritage were obtained from Wiedmann [5] study. In their study, Cifci et al. [54] have used the same scale and had translated the original 15-item scale items into Turkish, hence, Turkish translations of the scale items were adopted in our study. Brand trust scale items are adopted from Azizi's [55] study. Similarly, brand loyalty scale items were obtained from Netemeyer et al. [56] and purchase intentions scale items were obtained from Chang and Liu [57]. All scales used in the study have been previously used and translated into Turkish by Yildiz and Koc [58], hence requiring no new translations.

\subsection{Scale Equivalence}

Since the original scale items were developed in western countries, applying these measures in the culturally different Turkish setting might be problematic because the Turkish translation of the scales could present reliability and equivalence challenges, thereby, diminishing the precision of the estimators and reducing the power of statistical tests [59]. To minimize these potential issues, we decided to adapt the previous Turkish translations of these scale items by others who have already published their research, hence providing additional support for the scale equivalences. Furthermore, the number of items 
in these scales were reduced following Anderson and Gerbing's [60] recommendation of selecting the most salient ones to the model tested. Using the measurement purification process [61], seven-scale items were retained for brand heritage, three items were retained for each of the remaining constructs.

\section{Results}

\subsection{Descriptive Analysis}

Descriptive analysis of the data (see Table 1) indicates that two-thirds of the sample participants were male. Although the airline passengers in the US and Europe may be more evenly balanced in gender, there is not much information available about its distribution in the middle eastern countries. Traditionally, air travel is dominated by males in Turkey since air travel is mostly used for business travel purposes (higher levels of male employment) and business travelers have higher income levels. Considering the larger gaps between male and female employment proportion and income levels in Turkey, one would expect males in Turkey would account for a higher proportion of airline passengers. We did not use any stratified sampling to control the subject participation by gender but instead, we used a more randomized approach and asked the willing passengers to complete the survey in various airports. Moreover, Staub and Teber [62] study about Turkish Air passengers' characteristics reported that they had a $60 \%$ to $40 \%$ male-female sample, supporting the argument of higher concentration of male airline passengers in Turkey. Hence, the malefemale ratio obtained in our sample may be considered acceptable in the context of the Turkish air passengers. A majority $(70 \%)$ of the travelers indicated pleasure as the main reason for their travel. Mostly college-educated (40\%) and earning an approximately 1000 USD average monthly net income. The age group was uniformly distributed with the highest group being the 36 to 45 age group (25\%). Economy is considered the most important factor when buying an airline ticket $(40 \%)$ and Turkish Airlines received the highest preference among other airlines operating in Turkey (40\%). Finally, almost $70 \%$ of the subjects were from the four largest cities in Turkey (Istanbul, Ankara, Izmir, and Adana).

Table 1. Profile of the air travelers who participated in the study.

\begin{tabular}{|c|c|c|c|c|c|}
\hline Characteristics & Frequency & Relative Frequency (\%) & Characteristics & Frequency & Relative Frequency ( $\%)$ \\
\hline \multirow{2}{*}{ Gender } & & & \multicolumn{3}{|l|}{ Travel reason } \\
\hline & & & Business & 134 & 23.6 \\
\hline Male & 388 & 68.4 & Pleasure & 394 & 69.5 \\
\hline Female & 179 & 31.6 & Education & 22 & 3.9 \\
\hline Education & & & \multicolumn{3}{|l|}{$\begin{array}{l}\text { Average number of } \\
\text { travels per year }\end{array}$} \\
\hline Elementary school & 85 & 5.5 & 1 & 117 & 20.6 \\
\hline Middle school & 48 & 9.5 & 2 & 167 & 29.5 \\
\hline High school & 88 & 32.8 & 3 & 61 & 10.8 \\
\hline College & 124 & 40.6 & 4 & 78 & 13.8 \\
\hline Master's degree & 205 & 10.8 & 5 & 40 & 7.1 \\
\hline Doctoral degree & 550 & 0.9 & $6+$ & 104 & 18.3 \\
\hline Income (Turkish Lira) * & & & \multicolumn{3}{|l|}{ Airline Preference } \\
\hline 1300 or less & 85 & 15.0 & Anadolu Jet & 22 & 3.9 \\
\hline $1301-2500$ & 48 & 8.5 & Atlas Jet & 6 & 1.1 \\
\hline $2501-3700$ & 88 & 15.5 & Pegasus & 82 & 14.5 \\
\hline $3701-5000$ & 124 & 21.9 & Sun Express & 5 & 0.9 \\
\hline 5000 or more & 205 & 36.2 & THY & 227 & 40.0 \\
\hline Marital status & & & \multicolumn{3}{|l|}{$\begin{array}{l}\text { Most important factor } \\
\text { when choosing an airline }\end{array}$} \\
\hline Married & 358 & 63.1 & Economy & 249 & 43.9 \\
\hline Single & 184 & 32.5 & Safety & 74 & 13.1 \\
\hline Divorced & 18 & 3.2 & Friendly staff & 45 & 7.9 \\
\hline
\end{tabular}


Table 1. Cont.

\begin{tabular}{|c|c|c|c|c|c|}
\hline Characteristics & Frequency & Relative Frequency (\%) & Characteristics & Frequency & Relative Frequency (\%) \\
\hline Age & & & Comfort & 83 & 14.6 \\
\hline 25 or less & 74 & 13.1 & Flight timetable & 54 & 9.5 \\
\hline $26-35$ & 158 & 27.9 & & & \\
\hline $36-45$ & 140 & 24.7 & & & \\
\hline $46-55$ & 101 & 17.8 & & & \\
\hline $56-65$ & 66 & 11.6 & & & \\
\hline $65+$ & 19 & 3.4 & & & \\
\hline \multirow{3}{*}{ Occupation } & \multicolumn{5}{|c|}{ Data collection city } \\
\hline & & & Adana & 74 & 13.1 \\
\hline & & & Amasya & 2 & 0.4 \\
\hline Housewife & 65 & 11.5 & Ankara & 61 & 10.8 \\
\hline Private/Public employee & 170 & 30.0 & Düzce & 1 & 0.2 \\
\hline Technician & 10 & 1.8 & Erzurum & 35 & 6.2 \\
\hline Professional & 56 & 9.9 & Gaziantep & 55 & 9.7 \\
\hline Manager & 61 & 10.8 & İstanbul & 181 & 31.9 \\
\hline Self-employed & 123 & 21.7 & İzmir & 63 & 11.1 \\
\hline Retired & 32 & 5.6 & Samsun & 40 & 7.1 \\
\hline Unemployed & 14 & 2.5 & Trabzon & 25 & 4.4 \\
\hline Student & 36 & 6.3 & Van & 30 & 5.3 \\
\hline
\end{tabular}

Notes: ${ }^{*}$ At the time of data collection, the exchange rate was 1 USD $=6 \mathrm{TL}$.

\subsection{Traveler Perceptions of Airlines}

We then checked how travelers perceived various airlines operating in Turkey in terms of their relationship with the most important factors for airline selection. In other words, we wanted to obtain their perceptual maps about each airline and how closely they were perceived to be associated with the most important airline selection attributes they stated. For this exploratory analysis, we used Correspondence Analysis (CA). Briefly, CA decomposes the Chi-square measure of association of the contingency table into components similar to the principal component analysis $[63,64]$. In this analysis, we used only the topmost important factors for airline selection and their preferred airlines as the input for the CA. Figure 2 displays the results of the correspondence analysis.

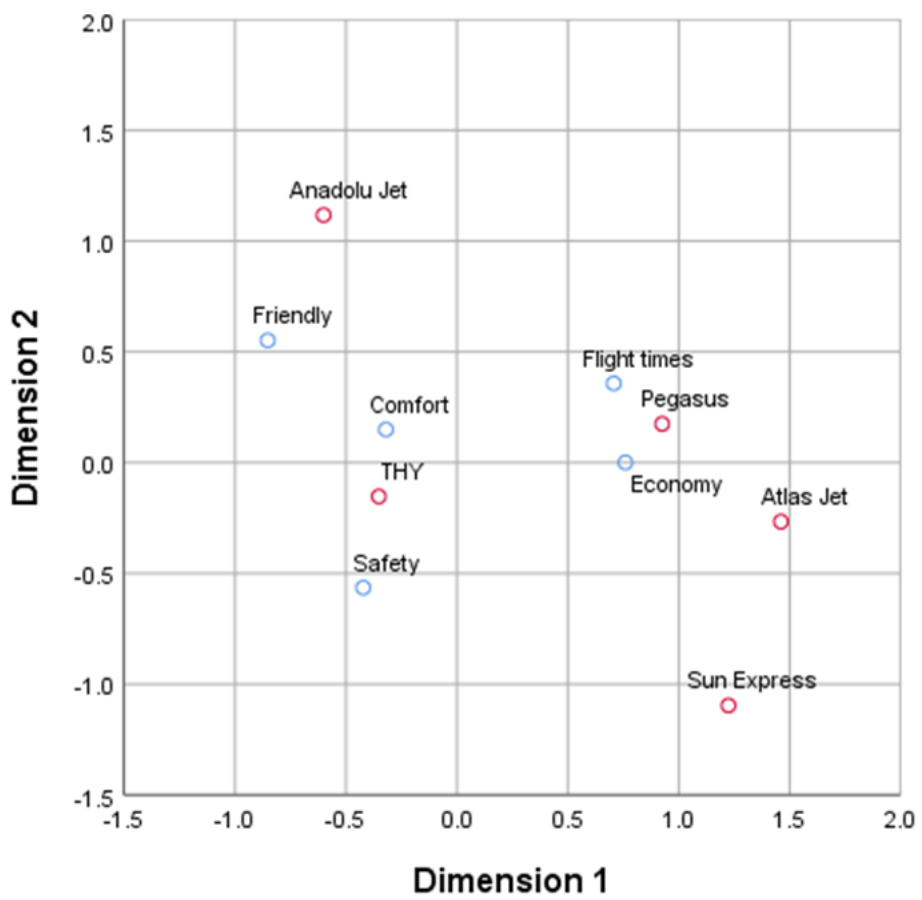

Figure 2. Correspondence analysis plot (Topmost important factors versus airlines). 
CA plot in Figure 2 indicates that the top two most important factors that were perceived to be closely associated with Turkish Airlines (TA) were comfort and safety. Anadolu Jet, a brand of Turkish Airlines was located near Turkish Airlines and was perceived to have friendly staff. On the other hand, economy and flight timetable were the factors more closely perceived to be associated with Pegasus and Atlas Jet.

\subsection{Construct Reliability and Validity}

We first checked the reliability of all the constructs used in the study (Table 2). Reliability scores of all constructs exceeded the minimum alpha levels suggested $(\alpha=0.70)$ in the literature $[59,61]$ ranging from 0.80 to 0.91 . Hence, we concluded that the reliability scores obtained in our study are sufficient for moving forward with testing and validating the structural relationships identified in our model. Table 2 also provides other descriptive results along with Cronbach's alphas for the constructs used in the model.

Table 2. Measurement scale, Items, Means, and Cronbach's Alphas.

\begin{tabular}{|c|c|c|}
\hline Constructs and Items & Mean & Alpha \\
\hline Brand Heritage & & 0.912 \\
\hline - $\quad$ Brand TA* sets the valuation standard for other brands. & 3.75 & \\
\hline - The services of brand TA are a part of the national treasure. & 3.81 & \\
\hline - I have an absolutely clear image of brand TA. & 3.76 & \\
\hline - Brand TA has a strong cultural meaning. & 3.79 & \\
\hline - $\quad$ Brand TA represents honesty and truthfulness. & 3.78 & \\
\hline - $\quad$ Brand TA is highly known in society. & 4.03 & \\
\hline - $\quad$ Brand TA has a very good reputation. & 3.90 & \\
\hline Brand Trust & & 0.879 \\
\hline - TA is a brand name that never disappoints me & 3.73 & \\
\hline - TA brand name guarantee satisfaction & 3.75 & \\
\hline - I could rely on the TA brand name to solve the problem & 3.62 & \\
\hline Brand Loyalty & & 0.80 \\
\hline - I think I am affiliated with the Turkish Airlines brand. & 3.33 & \\
\hline - I trust the TA brand & 3.81 & \\
\hline - I am loyal to the brand TA. & 3.11 & \\
\hline Intentions to Buy & & 0.907 \\
\hline $\begin{array}{l}\text { - Even if the features of other brands are as good as TA, I still prefer the } \\
\text { Turkish Airlines brand. }\end{array}$ & 3.20 & \\
\hline - $\quad$ Although other brands offer better options, I prefer the brand TA. & 3.02 & \\
\hline - $\quad$ I prefer the TA in my new flight purchases. & 3.28 & \\
\hline
\end{tabular}

We then evaluated the unidimensionality and discriminant validity of the constructs [60]. The multidimensionality and fit of the measurement model for each construct were tested using confirmatory factor analysis (hereafter CFA). Testing of the measurement model allows us to determine if the observed variables are measuring the underlying theoretical constructs and if they provide some evidence of an acceptable model fit. The number of indicator variables used for each construct (Brand Heritage, Brand Trust, Brand Loyalty, and Purchase Intention) in the model was reduced by a purification process [61], hence, leaving the most salient scale items to measure the constructs in the final model. The IBM SPSS AMOS software modification index was used in the pruning process. All model fit indices for the measurement model met or exceeded the levels suggested in the literature.

We then tried to assess the discriminant validity to see if the constructs are distinct from other constructs. Results are summarized in Table 3. The AVE for all constructs used in the model ranged from 0.57 to 0.71 and they were all greater than the AVE criterion of 0.50 suggested in the literature [64]. Table 3 displays that the tested model had acceptable levels of discriminant validity with the construct intercorrelations (IC) being less than the 
corresponding square root of the AVEs for each construct [65] with only two exceptions. All intercorrelations of constructs were significant at $p<0.05$ level.

Table 3. Overall model construct means $\left(\mathrm{x}^{-}\right)$, standard deviations (SD), average variance extracted (AVE), and Construct Intercorrelations.

\begin{tabular}{ccccccc}
\hline & Mean & STD & Brand Heritage & Brand Trust & Brand Loyalty & Intention to Buy \\
\hline Overall AVE & & & 0.602 & 0.706 & 0.582 & 0.572 \\
\hline Brand Heritage & 3.83 & 0.93 & $\mathbf{0 . 7 7 6}$ & & & \\
Brand Trust & 3.70 & 0.96 & 0.929 & $\mathbf{0 . 8 4 0}$ & 0.723 & 0.763 \\
Brand Loyalty & 3.41 & 1.18 & 0.680 & 0.671 & 0.945 & $\mathbf{0 . 7 5 6}$ \\
Intention to buy & 3.17 & 1.23 & 0.628 & & \\
\hline
\end{tabular}

Notes: The square roots of AVEs are shown in diagonals (bold). Correlations for each construct in the model are in the lower half of the table. All correlation coefficients are significant at the $p<0.05$ level. All but two construct intercorrelations are less than the corresponding square root of the AVEs.

Although it would have been preferred to obtain stronger discriminant validity, it is important to note that these results need to be evaluated on the basis of the entire information provided. Consistent with other researchers (e.g., [65]), we think that the AVEs obtained in this study meet or exceed the acceptable levels of discriminant validity. All AVEs were of equal or higher than the suggested SIC level in the literature. This suggests that sufficient convergent validity was obtained. Since all AVEs are larger than their respective SICs, the results obtained in this study are acceptable and sufficient to test the hypothesized structure. Finally, the standardized weights (i.e., all above 0.50 ) and overall composite reliability (i.e., CR values ranged between 0.80 and 0.91 ) are consistent with Fornell and Larcker's [66] suggested criterion of 0.70 for adequate convergence or internal consistency. Therefore, when taken together, the results provide reasonable support for the convergent validity of the constructs used in the model. In addition, the model fit was relatively good as measured by various goodness-of-fit measures.

\subsection{Hypotheses Testing}

To test the hypothesized relationships in Figure 1, we used a structural equation model. A commonly used approach suggested by Chou and Bentler [67] was used to estimate the measurement model (the maximum likelihood estimation method).

We first estimated the structural relationships between Brand Heritage and Purchase Intentions. H1 predicted that Brand Heritage is positively related to Purchase Intention. The results are shown in Figure 3. The standardized path coefficient is positive and significant $(\beta=0.63, \mathrm{t}=13.801, p<0.000)$, supporting the positive impact of Brand Heritage on PI with acceptable levels of model fit (Chi-square $=199.49 ; \mathrm{GFI}=0.933 ; \mathrm{CFI}=0.956$; RMSEA $=0.093$ ) levels. Model R-squared (0.39) was found to be acceptable as well.

We then tested the entire model by including Brand Trust and Brand Loyalty in the model. The results of the structural analysis are given in Figure 4.

$\mathrm{H} 2$ predicted that Brand Heritage would be positively related to Brand Trust. The standardized path coefficient displayed in Figure 4 is positive and significant $(\beta=0.93$, $t=20.413, p<0.000$ ), supporting the positive impact of Brand Heritage on Brand Trust.

$\mathrm{H} 3$ predicted that Brand Trust would be positively related to Brand Loyalty. The standardized path coefficient displayed in Figure 4 is positive and significant $(\beta=0.73$, $\mathrm{t}=13.705, p<0.000$ ), supporting the positive impact of Brand Trust on Brand Loyalty.

$\mathrm{H} 4$ predicted that Brand Loyalty would be positively related to Purchase Intention. The standardized path coefficient displayed in Figure 4 is positive and significant $(\beta=0.96$, $t=13.955, p<0.000)$, supporting the positive impact of Brand Loyalty on Purchase Intention.

Finally, H5 predicted that Brand Trust and Brand Loyalty would mediate the relationships between Brand Heritage and PI. Using the procedure suggested by Iacobucci [68] for structural models, mediation effect would be present if the inclusion of Brand Trust and Brand Loyalty were to reduce the strength of the path coefficient between Brand Heritage 
and Purchase Intention. Figure 4 reveals that the path coefficient between Brand Heritage and Purchase Intention became statistically insignificant when we included Brand Trust and Brand Loyalty in the model, hence indicating a full mediation of the relationship, supporting H5. Model fit level was acceptable (Chi-square $=476.10 ; \mathrm{GFI}=0.906 ; \mathrm{CFI}=0.945$; RMSEA $=0.082$ ) and the model R-squared has improved substantially $(0.89)$. A summary of the hypotheses testing results is presented in Table 4.

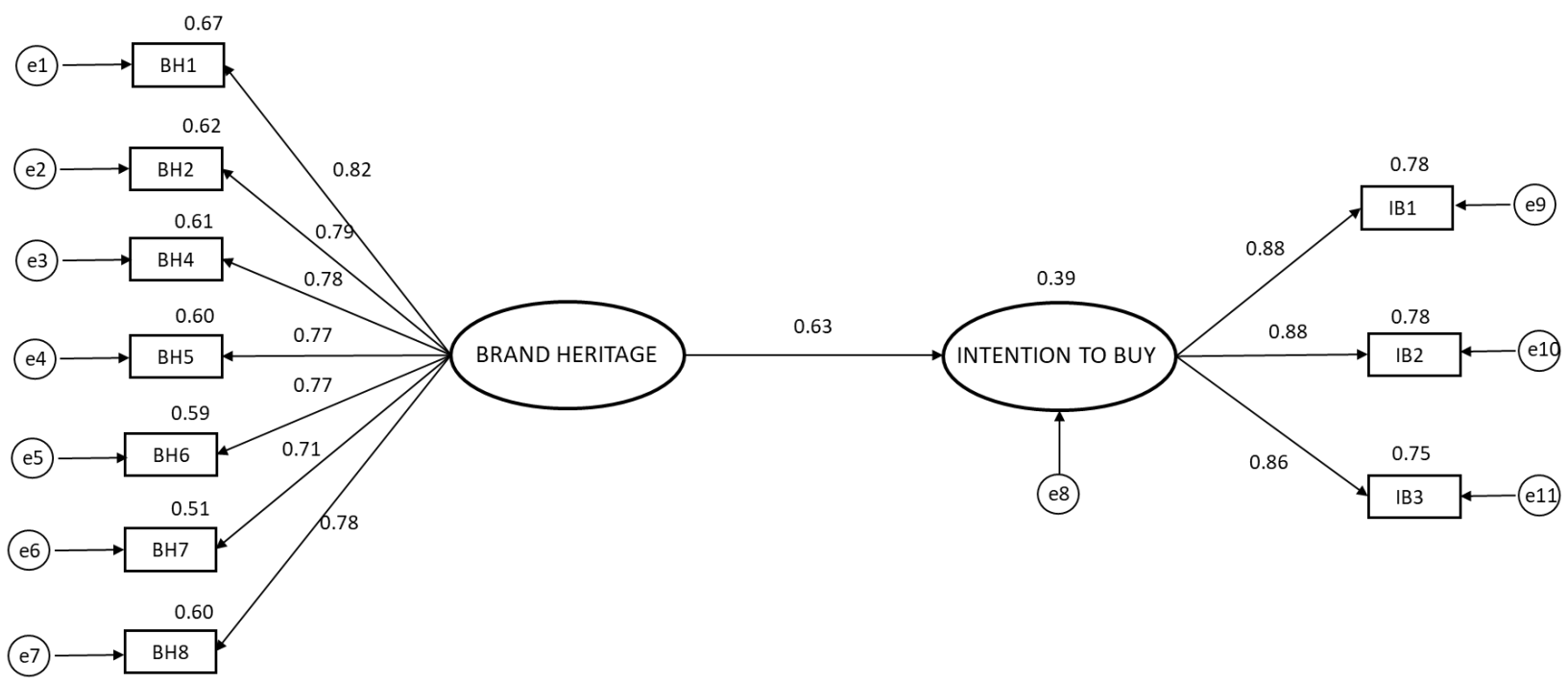

Chisquare $=199.499, \mathrm{p}$-value $=.000, \mathrm{GFI}=0.933, \mathrm{CFI}=0.956, \mathrm{RMSEA}=0.093$

Figure 3. Effects of Brand heritage on Intention to buy.

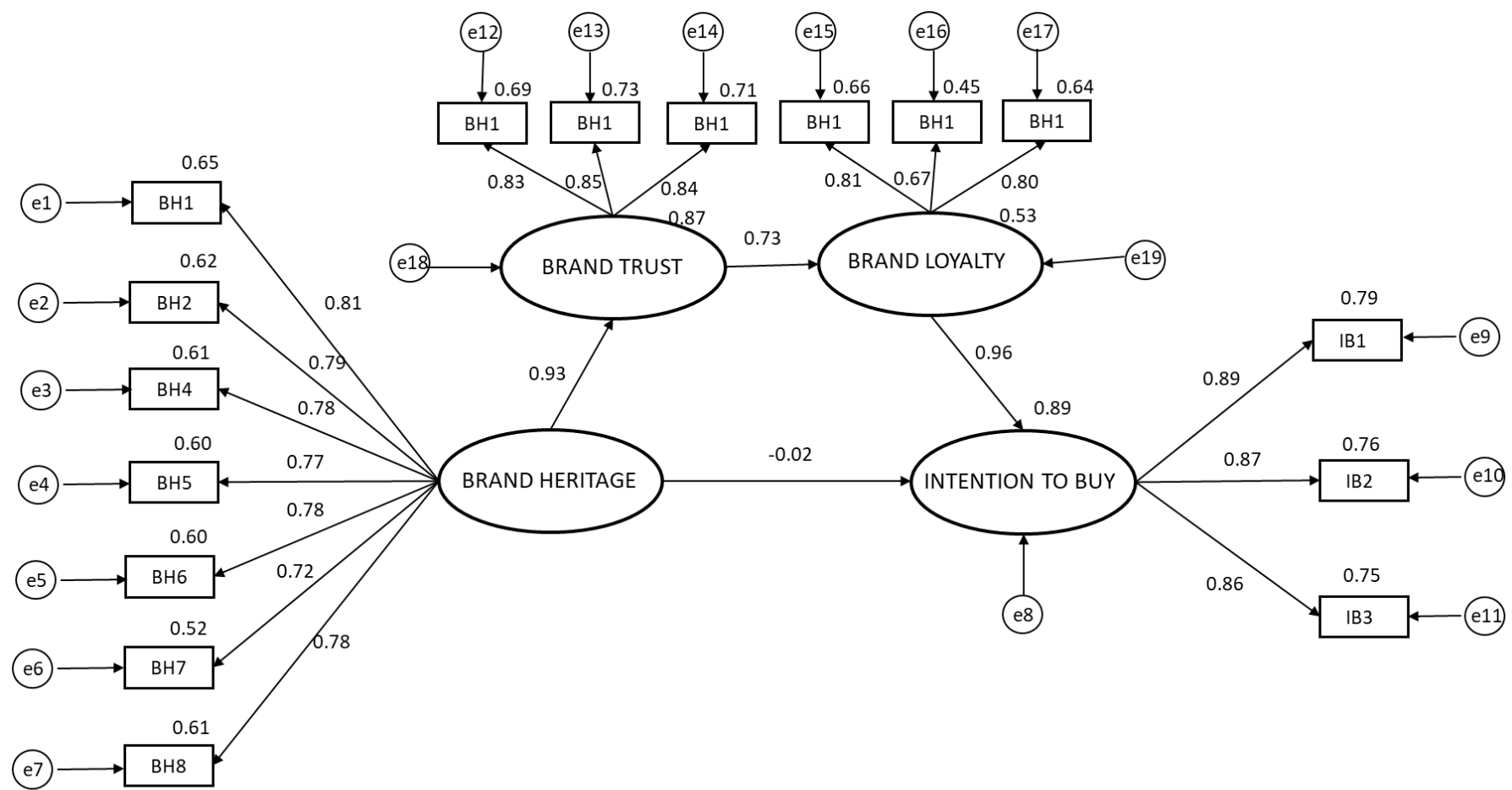

Chisquare $=476.100, \mathrm{p}$-value $=.000, \mathrm{GFI}=0.906, \mathrm{CFI}=0.945, \mathrm{RMSEA}=0.082$

Figure 4. Mediation effects of Brand trust and Brand loyalty. 
Table 4. Hypotheses testing results.

\begin{tabular}{ccc}
\hline Hypothesis & Description & Supported/Not Supported \\
\hline $\mathrm{H} 1$ & $\begin{array}{c}\text { Brand heritage will have a positive impact on } \\
\text { consumer purchase intentions. }\end{array}$ & Supported \\
\hline $\mathrm{H} 2$ & $\begin{array}{c}\text { Brand heritage will positively influence } \\
\text { perceived trust. }\end{array}$ & Supported \\
\hline $\mathrm{H} 3$ & $\begin{array}{c}\text { Higher levels of perceived trust will lead to } \\
\text { higher levels of customer loyalty. }\end{array}$ & Supported \\
\hline $\mathrm{H} 4$ & $\begin{array}{l}\text { Higher levels of customer loyalty will } \\
\text { positively influence purchase intentions. }\end{array}$ \\
\hline $\mathrm{H} 5$ & $\begin{array}{c}\text { The positive effect of brand heritage on } \\
\text { purchase intentions is mediated by brand } \\
\text { trust and brand loyalty. }\end{array}$ & Supported \\
\hline
\end{tabular}

\section{Discussion}

This study utilized the Commitment-Trust Theory as a theoretical framework to examine the relationship between brand heritage and purchase intentions of airline services. More specifically, our study focused on understanding how trust and loyalty influenced the brand heritage $\rightarrow$ purchase intentions relationships. Using the Commitment-Trust Theory, the study conceptualized that trust and loyalty would mediate the relationship between brand heritage and purchase intentions.

The initial model tested to reveal that brand heritage had a direct positive effect on consumers' purchase intentions for airline services. This is an expected result as similar support of this relationship was reported in the literature. Previous studies have also suggested that brand heritage influences consumers through their cognition and emotions, and established brand heritage perceptions usually lead to higher trust levels to the service provider. Moreover, trust has been considered as an antecedent for building loyal relationships between two parties. Hence, we conceptualized that both brand trust and loyalty would strengthen the relationships between brand heritage and purchase intentions. Accordingly, we then included brand trust and brand loyalty in the second structural model tested. Results revealed that when the trust and loyalty constructs were included in the model, the explanatory power of the structural model improved substantially but the path between brand heritage $\rightarrow$ purchase intentions became statistically insignificant, indicating that the relationship between these two constructs was fully mediated by the brand trust and loyalty. Our results confirm that the influence of brand heritage on consumers' behavioral intentions is more salient through the trust $\rightarrow$ loyalty path.

These results imply that brand trust and loyalty need to be developed before high levels of consumer commitment are formed. To explain this relationship, we argue that brand heritage and corporate identity reinforce consumers' positive emotions/feeling toward brands in terms of stability, reliability, consistency of brand image, and evidence from past performances and hence contribute to the development and maintenance of brand trust. As previous researchers concluded, brand heritage contributes to positive associations and feelings (e.g., "we are proud to have such a successful global company"); therefore, if the corporate communication were to be able to successfully invoke a brand's heritage (e.g., Turkish Airlines), that would contribute to positive consumer emotions and trust, and promoting loyalty and behavioral commitment.

Our study contributes to the literature by providing additional empirical evidence of the mediating roles of brand trust and loyalty in the relationship between brand heritage and behavioral commitment. The results confirmed the relationship between brand heritage and purchase intentions in a culturally different emerging market, where identity and heritage are well communicated traditional cultural values in the society. Building on Erdem and Swait's [69] study, brand heritage signals consistency, stability, and performance and increases brand trust, which ultimately contributes to loyalty and commitment. 


\section{Managerial Implications and Conclusions}

Since brand heritage is related to the past, present, and future of a brand, it can be used as an important signal in repositioning an existing or new brand, especially during times of high levels of uncertainty and when consumers are seeking additional justifications for their purchase decisions. The airline industry has been significantly influenced by the COVID-19 pandemic. During such uncertain times, travelers may be more willing to rely on brands that they can trust, or service providers will be able to take the necessary precautions to provide a safer travel environment. Therefore, by communicating their brand heritage to establish connections with the company's long history, core values, and positive track records, companies can unravel the benefits of brand heritage. Using consistent marketing communications and symbols (e.g., in-flight attendant uniforms, emphasis on traditional cultural values such as hospitality, ceremonies, and visible actions that create a welcoming atmosphere), consumers' brand heritage perceptions may be proactively influenced and managed. However, it is crucial to note that the role of brand heritage on purchase intentions may not be fully observable unless trust and loyalty are developed. Managers' focus should be on invoking cultural and personal associations along with enhancing trust by articulating competence, sincerity, customer focus, and relationships through marketing mix decisions. Although brand trust is an important antecedent for loyalty, companies also need to develop various reward systems to enhance and encourage customer loyalty.

In this study, a large sample, collected from the passengers in various airports, was utilized. Moreover, established scales and theories were used to test the hypothesized relationships in the conceptual model. Despite these strengths of the study, it is important to acknowledge potential limitations and emphasize that caution needs to be taken when generalizing these results to the broader populations are beyond the scope of this study. Hence, since the data are collected in a single country (Turkey), generalizability to other culturally different environments may be limited. Turkish culture is more collective, cultural heritage and traditional values are promoted explicitly and encourage loyalty and relationships. It is necessary that these results need to be validated in culturally different environments. Second, this study uses a single product (service) to test the conceptual model. Using products from different industries may offer additional insights to researchers and practitioners alike. Moreover, although the ownership of Turkish Airlines has changed since the last two decades, it has been known as a state-owned enterprise for a long time and consumers may still perceive it that way. It is important to test the conceptualized relationships in this study using brands that do not have lingering state-ownership perceptions among customers.

Author Contributions: Conceptualization, D.Z. and A.K.; methodology, D.Z.; software, A.K.; validation, D.Z., A.K.; formal analysis, A.K.; investigation, D.Z.; resources, D.Z.; data curation, A.K.; writing-original draft preparation, D.Z., A.K.; writing—review and editing, D.Z., A.K.; visualization, D.Z.; supervision, A.K.; project administration, D.Z.; funding acquisition, D.Z. All authors have read and agreed to the published version of the manuscript.

Funding: This research received no external funding.

Institutional Review Board Statement: Not applicable.

Informed Consent Statement: When subjects agreed to participate in the study, that was considered Implied Consent.

Data Availability Statement: The data used in this study may be made available on request from the corresponding author.

Acknowledgments: The authors would like to thank the anonymous referees and journal editors for their valuable and constructive feedback.

Conflicts of Interest: The authors declare no conflict of interest. 


\section{References}

1. Aaker, D.A. Leveraging the Corporate Brand. Calif. Manag. Rev. 2004, 46, 6-18. [CrossRef]

2. Keller, K.L. Conceptualizing, Measuring, and Managing Customer-Based Brand Equity. J. Mark. 2004, 57, 1-22. [CrossRef]

3. Rose, G.M.; Merchant, A.; Orth, U.R.; Horstmann, F. Emphasizing Brand Heritage: Does It Work? And How? J. Bus. Res. 2016, 69, 936-943. [CrossRef]

4. Santos, F.P.; Burghausen, M.; Balmer, J.M.T. Heritage Branding Orientation: The Case of Ach. Brito and the Dynamics between Corporate and Product Heritage Brands. J. Brand Manag. 2016, 23, 67-88. [CrossRef]

5. Wiedmann, K.P.; Hennigs, N.; Schmidt, S.; Wuestefeld, T. Drivers and Outcomes of Brand Heritage: Consumers' Perception of Heritage Brands in The Automotive Industry. J. Mark. Theory Pract. 2011, 19, 205-220. [CrossRef]

6. Wiedmann, K.P.; Hennigs, N.; Schmidt, S.; Wuestefeld, T. The Importance of Brand Heritage as A Key Performance Driver in Marketing Management. J. Brand Manag. 2011, 19, 182-194. [CrossRef]

7. Urde, M.; Greyser, S.A.; Balmer, J.M.T. Corporate Brands with A Heritage. J. Brand Manag. 2007, 15, 4-19. [CrossRef]

8. Hakala, U.; Lätti, S.; Sandberg, B. Operationalising Brand Heritage and Cultural Heritage. J. Prod. Brand Manag. 2011, 20, 447-456. [CrossRef]

9. Merchant, A.; Rose, G.M. Effects of Advertising-Evoked Vicarious Nostalgia on Brand Heritage. J. Bus. Res. 2013, 66, 2619-2625. [CrossRef]

10. Taheri, B.; Farrington, T.; Curran, R.; O'Gorman, K. Sustainability and The Authentic Experience Harnessing Brand Heritage: A Study from Japan. J. Sustain. Tour. 2018, 26, 49-67. [CrossRef]

11. Ballantyne, R.; Warren, A.; Nobbs, K. The Evolution of Brand Choice. J. Brand Manag. 2006, 13, 339-352. [CrossRef]

12. Loveland, K.E.; Smeesters, D.; Mandel, N. Still Preoccupied with 1995: The Need to Belong and Preference for Nostalgic Products. J. Consum. Res. 2010, 37, 393-408. [CrossRef]

13. Zeren, D.; Kalkan, A. Marka Mirasının Satın Alma Niyeti, Marka İmajı, Markaya Güven, Marka Sadakati ve Müssteri Tatmini Üzerine Etkisi. BMIJ 2019, 7, 2891-2909. [CrossRef]

14. Morgan, R.M.; Hunt, S.D. The Commitment-Trust Theory of Relationship Marketing. J. Mark. 1994, 58, 20-38. [CrossRef]

15. Morhart, F.; Malär, L.; Guèvremont, A.; Girardin, F.; Grohmann, B. Brand authenticity: An integrative framework and measurement scale. J. Consum. Psychol. 2015, 25, 200-218. [CrossRef]

16. Simms, C.D.; Trott, P. The Perceptions of the BMW Mini Brand: The Importance of Historical Associations and the Development of a Model. J. Prod. Brand Manag. 2006, 15, 228-238. [CrossRef]

17. Balmer, J.M.; Powell, S.M.; Hudson, B.T. Brand Heritage and The Renaissance of Cunard. Eur. J. Mark. 2011, 45, $1538-1556$.

18. Ghodeswar, B.M. Building Brand Identity in Competitive Markets: A Conceptual Model. J. Prod. Brand Manag. 2008, 17, 4-12. [CrossRef]

19. Balmer, J.M.; Hudson, B.T. Corporate Heritage Brands: Mead's Theory of the Past. Corp. Commun. Int. J. $2013,18,347-361$.

20. Napoli, J.; Dickinson, S.J.; Beverland, M.B.; Farrelly, F. Measuring Consumer-Based Brand Authenticity. J. Bus. Res. 2014, 67, 1090-1098. [CrossRef]

21. Wuestefeld, T.; Hennigs, N.; Schmidt, S.; Wiedmann, K.P. The Impact of Brand Heritage on Customer Perceived Value. Der Markt 2012, 51, 51-61. [CrossRef]

22. Burghausen, M.; Balmer, J.M.T. Corporate Heritage Identity Management and the Multimodal Implementation of a Corporate Heritage Identity. J. Bus. Res. 2014, 67, 2311-2323. [CrossRef]

23. Moorman, C.; Deshpande, R.; Zaltman, G. Factors Affecting Trust in Market Research Relationships. J. Mark. 1993, 57, 81-101. [CrossRef]

24. Sherman, S. Are Strategic Alliances Working? Fortune 1992, 126, 77-78.

25. Spekman, R.E. Strategic Supplier Selection: Understanding Long-term Buyer Relationships. Bus. Horiz. 1988, 31, 75-81. [CrossRef]

26. Barbalet, J. Social Emotions: Confidence, Trust, and Loyalty. Int. J. Sociol. Soc. Policy 1996, 16, 75-96. [CrossRef]

27. Chaudhuri, A.; Holbrook, M.B. The Chain of Effects from Brand Trust and Brand Affect to Brand Performance: The Role of Brand Loyalty. J. Mark. 2001, 65, 81-93. [CrossRef]

28. Dunn, J.R.; Schweitzer, M.E. Feeling and Believing: The Influence of Emotion on Trust. J. Personal. Soc. Psychol. 2005, 88, 736-741. [CrossRef]

29. Schurr, P.H.; Ozanne, J.L. Influences on Exchange Processes: Buyers' Preconceptions of a Seller's Trustworthiness and Bargaining Toughness. J. Consum. Res. 1985, 11, 939-953. [CrossRef]

30. Aydin, S.; Ozer, G. The Analysis of Antecedents of Customer Loyalty in the Turkish Mobile Telecommunication Market. Eur. J. Mark. 2005, 39, 910-925. [CrossRef]

31. Dehdashti, Z.; Kenari, M.J.; Bakhshizadeh, A. The Impact of Social Identity of Brand on Brand Loyalty Development. Manag. Sci. Lett. 2012, 2, 1425-1434. [CrossRef]

32. Melewar, T.C.; Foroudi, P.; Gupta, S.; Kitchen, P.J.; Foroudi, M.M. Integrating Identity, Strategy and Communications for Trust, Loyalty and Commitment. Eur. J. Mark. 2017, 51, 572-604. [CrossRef]

33. He, H.; Li, Y.; Harris, L. Social Identity Perspective on Brand Loyalty. J. Bus. Res. 2012, 65, 648-657. [CrossRef]

34. Oliver, R.L. Whence Consumer Loyalty? J. Mark. 1999, 63, 33-44. [CrossRef]

35. Hirschman, A.O. Exit, Voice, and Loyalty: Responses to Decline in Firms, Organizations, and States; Harvard University Press: Cambridge, MA, USA, 1970. 
36. Jacoby, J.; Kyner, D.B. Brand Loyalty vs. Repeat Purchasing Behavior. J. Mark. Res. 1973, 10, 1-9. [CrossRef]

37. Uncles, M.D.; Dowling, G.R.; Hammond, K. Customer Loyalty and Customer Loyalty Programs. J. Consum. Mark. 2003, 20, 294-316. [CrossRef]

38. Knox, S.; Walker, D. Measuring and Managing Brand Loyalty. J. Strateg. Mark. 2001, 9, 111-128. [CrossRef]

39. Beverland, M. The 'Real Thing': Branding Authenticity in the Luxury Wine Trade. J. Bus. Res. 2006, 59, 251-258. [CrossRef]

40. Erdem, T.; Swait, J. Brand Equity as a Signaling Phenomenon. J. Consum. Psychol. 1998, 7, 131-157. [CrossRef]

41. Pécot, M.; Gavilanes, J.; Sáenz De Viteri, A. Tales of Informality: Tourism Development in Four Ecuadorian Beaches. Tour. Plan. Dev. 2018, 15, 584-599. [CrossRef]

42. Chebat, J.-C.; Slusarczyk, W. How Emotions Mediate the Effects of Perceived Justice on Loyalty in Service Recovery Situations: An Empirical Study. J. Bus. Res. 2005, 58, 664-673. [CrossRef]

43. Gambetta, D. Trust: Making and Breaking Cooperative Relations; Blackwell: Oxford, UK, 1990.

44. Fournier, S. Consumers and Their Brands: Developing Relationship Theory in Consumer Research. J. Consum. Res. 1998, 24, 343-373. [CrossRef]

45. Holmes, J.G.; Rempel, J.K. Trust in Close Relationships. In Close Relationships; Hendrick, C., Ed.; Sage: Newbury Park, CA, USA, 1989; pp. 187-220.

46. Hanzaee, K.H.; Andervazh, L. The Influence of Brand Loyalty on Cosmetics Purchase Intention of Iranian Female Consumers. J. Basic Appl. Sci. Res. 2012, 2, 5389-5398.

47. Chen, Y.-S. The Drivers of Green Brand Equity: Green Brand Image, Green Satisfaction, and Green Trust. J. Bus. Ethics 2010, 93, 307-319. [CrossRef]

48. Reichheld, F.F.; Teal, T. The Loyalty Effect; Harvard Business School Press: Boston, MA, USA, 1996.

49. Maden, D. The Concept of Brand Culture: A Qualitative Analysis Directed to Turkish Airlines. Mediterr. J. Soc. Sci. 2013, 4, 42. [CrossRef]

50. Atas, U.; Morris, G.; Bat, M. The Implementation of Sponsorship in Corporate Branding: A Case Study of Turkish Airlines. Glob. Media J. TR Ed. 2015, 6, 35-53.

51. Aaker, D.A.; Kumar, V.; Day, G.S.; Lawley, M.; Stewart, D.W. Marketing Research: The Second Pacific Rim Edition; John Wiley and Sons: Milton, QLD, Australia, 2007.

52. Zikmund, W.R. Business Research Methods; The Dryden Press: Fort Worth, TX, USA, 1997.

53. Kurtuluş, S.; Kurtuluş, K.; Ozturk, S. Research Methodology in Marketing Publications in Turkey: Review and Evaluation. In Proceedings of the 6th International Multi Conference on Society, Cybernetics and Informatics, Orlando, FL, USA, 17-20 June 2012; pp. 212-216.

54. Cifci, S.; Nurtanıs Velioglu, M.; Ozbakir Umut, M. Marka Mirası Kavramı ve Hizmetlerde Marka Mirasına Yönelik Bir Ölçek Değerlendirilmesi. Anadolu Üniversitesi Sos. Bilimler Derg. 2014, 14, 105-114.

55. Azizi, S. A Model of Factors Affecting Foreign Brand Trust. J. Compet. 2014, 6, 20-31. [CrossRef]

56. Netemeyer, R.G.; Krishnan, B.; Pullig, C.; Wang, G.; Yagci, M.; Dean, D.; Ricks, J.; Wirth, F. Developing and Validating Measures of Facets of Customer-Based Brand Equity. J. Bus. Res. 2004, 57, 209-224. [CrossRef]

57. Chang, H.H.; Liu, Y.M. The Impact of Brand Equity on Brand Preference and Purchase Intentions in the Service Industries. Serv. Ind. J. 2009, 29, 1687-1706. [CrossRef]

58. Yildiz, E.; Koc, M.E. Marka Mirası ve Marka Güveninin Satın Alma Niyeti, Müşteri Tatmini ve Marka Sadakati Üzerindeki Etkileri. Dumlupınar Üniversitesi Sos. Bilimler Derg. 2017, 86-104.

59. Davis, H.L.; Douglas, S.P.; Silk, A.J. Measure Unreliability: A Hidden Threat to Cross-national Marketing Research? J. Mark. 1981, 45, 98-109. [CrossRef]

60. Anderson, J.C.; Gerbing, D.W. Structural Equation Modeling in Practice: A Review and Recommended Two-Step Approach. Psychol. Bull. 1988, 103, 411. [CrossRef]

61. Jöreskog, K.G.; Dag, S. PRELIS: A Preprocessor for LISREL; Scientific Software: Mooresville, NC, USA, 1988.

62. Staub, S.; Teber, S. Turkish Air Passenger Characteristics and Approach to Self Service Applications Provided by Turkish Air Transport Corporations. Procedia Soc. Behav. Sci. 2015, 195, 32-41. [CrossRef]

63. Greenacre, M.J. Theory and Applications of Correspondence Analysis; Academic Press Inc.: London, UK, 1984.

64. Greenacre, M.J. The Carroll-Green-Schaffer Scaling in Correspondence Analysis: A Theoretical and Empirical Appraisal. J. Mark. Res. 1989, 26, 358-365. [CrossRef]

65. Bagozzi, R.P.; Yi, Y. On the Evaluation of Structural Equation Models. J. Acad. Mark. Sci. 1998, 16, 74-94. [CrossRef]

66. Fornell, C.; Larcker, D.F. Structural Equation Models with Unobservable Variables and Measurement Error: Algebra and Statistics. J. Mark. Res. 1981, 18, 382-388. [CrossRef]

67. Chou, C.P.; Bentler, P.M. Application of AIC to Wald and Lagrange multiplier tests in covariance structure analysis. Multivar. Behav. Res. 1996, 31, 351-370. [CrossRef]

68. Iacobucci, D. Mediation Analysis; Sage: Thousand Oaks, CA, USA, 2008.

69. Erdem, T.; Swait, J. Brand Credibility, Brand Consideration, and Choice. J. Consum. Res. 2004, 31, 191-198. [CrossRef] 